\title{
LETTER
}

\section{Tissue hypoxia during acute hemorrhage}

\author{
Philippe Haouzi* \\ See related commentary by Calzia et al., http://ccforum.com/content/16/6/183
}

Calzia and colleagues argue [1] that tissue hypoxia in a rat model of hemorrhage that led to an oxygen deficit of $120 \mathrm{ml} / \mathrm{kg}$ with hyperlactacidemia [2] may be modest, and may not affect hydrogen sulfide oxidation since '... the arterial oxygen partial pressure was still normal ...' [1]. This contention requires clarification.

A relative hyperventilation is the rule in most experimental models of hemorrhage [2,3], since the reduction in oxygen uptake/consumption $\left(\mathrm{V}_{2}\right)$ is always larger than that in alveolar ventilation (ن்A). Alveolar oxygen partial pressure therefore increases during hemorrhage, as it is the ratio between $\dot{\mathrm{VO}}_{2}$ and $\dot{\mathrm{VA}}$ (and not the absolute level of $\dot{\mathrm{VA}}$ ) that dictates the partial pressure of oxygen in the alveolar gas $\left(\mathrm{PAO}_{2}\right)$ :

$$
\mathrm{PAO}_{2}=\mathrm{PIO}_{2}-k \dot{\mathrm{V} O}{ }_{2} / \dot{\mathrm{VA}}
$$

This tells us very little about the level of tissue hypoxia.

In all of the models used to study an acute hemorrhage, the baseline oxygen delivery rate $\left(\mathrm{DO}_{2}=\dot{\mathrm{Q}}_{\mathrm{a}} \mathrm{O}_{2}\right)$ is three to four times higher than $\dot{\mathrm{VO}}_{2}$, despite a large discrepancy in $\dot{\mathrm{VO}}_{2}$ per kilogram between a $500 \mathrm{~g}$ rat, a $20 \mathrm{~kg}$ pig or a human being: cardiac output, $\mathrm{DO}_{2}$ and $\dot{\mathrm{V}}_{2}$ do share a similar allometric function with body weight, so that the blood oxygen content is the same in most species. $\dot{\mathrm{Q}}$ drops dramatically during hemorrhage, reducing $\mathrm{DO}_{2}$. The level of $\mathrm{DO}_{2}$ decreases up to 10 times while $\dot{\mathrm{VO}}_{2}$ drops by four times regardless of the size of animal chosen $[3,4]$ so that both $\mathrm{DO}_{2}$ and $\dot{\mathrm{VO}}_{2}$ reach one-third of the baseline metabolic rate at the end of a severe hemorrhage! This should certainly lead to one of the most severe forms of tissue hypoxia - with normal arterial blood oxygen partial pressure - unless a decrease in oxygen demand contributes significantly to the reduction in $\mathrm{VO}_{2}$ induced by the decline in $\mathrm{DO}_{2}$. Indeed, although the relationship between $\mathrm{DO}_{2}$ and $\mathrm{V}_{2}$ is similar across species, the meaning of a reduction in $\mathrm{VO}_{2}$ can greatly differ among animal models according to their ability to decrease the oxygen demand $[3,5]$ - a phenomenon present during hemorrhage in small mammals [3]. It is eventually this ability to modify oxygen demand during a hemorrhage, in keeping with $\mathrm{DO}_{2}$, which controls the level of tissue hypoxia, and not the absolute levels of $\mathrm{PaO}_{2}, \mathrm{DO}_{2}$ or $\dot{\mathrm{VO}}_{2}$.

\section{Abbreviations \\ $\mathrm{Ca}_{2} \mathrm{O}_{2^{\prime}}$ concentration (content) of oxygen in the arterial gas; $\mathrm{DO}_{2^{\prime}}$ rate of oxygen delivery $\left(\dot{Q}_{2} \mathrm{O}_{2}\right) ; \mathrm{PAO}_{2^{\prime}}$ partial pressure of oxygen in the alveolar gas; $\mathrm{PIO}_{2^{\prime}}$ partial pressure of oxygen in the inspired gas; $\dot{\mathrm{Q}}$, cardiac output; $\dot{\mathrm{V}} \mathrm{A}$, alveolar ventilation; $\dot{\mathrm{V}}_{2^{\prime}}$ oxygen uptake/consumption.}

\section{Competing interests}

The author declares that he has no competing interests.

Published: 28 March 2013

\section{References}

1. Calzia $\mathrm{E}$, Radermacher $\mathrm{P}, \mathrm{Olson} \mathrm{KR}$ : Endogenous $\mathrm{H}_{2} \mathrm{~S}$ in hemorrhagic shock: innocent bystander or central player? Crit Care 2012, 16:183.

2. Van De Louw $\mathrm{A}$, Haouzi P: Oxygen deficit and $\mathrm{H}_{2} \mathrm{~S}$ in hemorrhagic shock in rats. Crit Care 2012, 16:178.

3. Haouzi $P$, Van de Louw A: Uncoupling mitochondrial activity maintains body $\mathrm{VO}_{2}$ during hemorrhage-induced $\mathrm{O}_{2}$ deficit in the anesthetized rat. Respir Physiol Neurobiol 2013, 186:87-94.

4. Vincent JL, De Backer D: Oxygen transport - the oxygen delivery controversy. Intensive Care Med 2004, 30:1990-1996.

5. Haouzi P: Murine models in critical care research. Crit Care Med 2011, 39:2290-2293.

doi:10.1186/cc12519

Cite this article as: Haouzi P: Tissue hypoxia during acute hemorrhage.

Critical Care 2013, 17:423.
*Correspondence: phaouzi@hmc.psu.edu

Division of Pulmonary and Critical Care Medicine, Penn State University College of Medicine, Penn State Hershey Medical Center, 500 University Drive, Hershey, PA 17033, USA 